\title{
Socioeconomic and Ethnobotanical Importance of the Breadfruit Tree (Artocarpus Communis J. G \& G. Forster) in Benin
}

\author{
Asaël J. Dossa, Msc, PhD Student \\ Juste M. Amanoudo, Msc, PhD Student \\ Towanou Houetchegnon, PhD, Assistant professor \\ Christine Ouinsavi, PhD, Full professor \\ Laboratory of Studies and Forestry Research (LERF), \\ Faculty of Agronomy, University of Parakou, Parakou, Bénin
}

Doi: 10.19044/esj.2018.v14n24p447 URL:http://dx.doi.org/10.19044/esj.2018.v14n24p447

\begin{abstract}
This study aims to evaluate ethnobotanical knowledge that populations hold and income from the exploitation of the breadfruit (Artocarpus communis) in southern Benin. The data collected by interview and focus group are related to the uses of Artocarpus communis, harvest methods and the habitat of specie. The results show that A. communis is used for: food, trade, artisanal, energetic, cultural and medicinal. Local populations know the species with unequal distribution among gender $($ Men ID $=0.75$ and $\mathrm{IE}=0.08)$ and Women (ID $=0.48$ and IE $=0.06$ ); and when it comes to age (Young ID $=0.56$ and $\mathrm{IE}=0.07$; Adult ID $=0.606$ and $\mathrm{IE}=0.08 ;$ Old ID $=0.75$ and $\mathrm{IE}=$ $0.1)$ suggesting that people make various uses of the species. The most used plant part was the fruit (VUT=11, 87). These organs (Fruits, Flowers, Leaf), are collected either by picking or collecting, (bark) by debarking and (root) by digging. $50.51 \%$ of people surveyed collected those organs on breadfruit trees present at homes, $14.65 \%$ on those present in fields, $11.62 \%$ in the dregs and $23.23 \%$ in fallow lands. The average fruit yield of an orchard is estimated at 17 tonnes/ha, which represents an average income of about 2817 USD/individual/year.
\end{abstract}

Keywords: Artocarpus communis, ethnobotanical importance, socioeconomic, Benin

\section{Introduction}

In Africa, Non-Timber Forest Products (NTFPs) play an important role in poverty reduction (Labouisse, 2016). They are wild or cultivated plants whose useful potential has been little exploited (Moupela, 2013) but 
contributes to the food security of local people in West Africa. Therefore, to achieve the goal of promoting good health, an inexpensive source of protein remains an ultimate step (FAO, 2002).

In Benin, the breadfruit tree (Artocarpus communis) is also an important staple food (Ragone, 2011; Labouisse, 2016) and one of many agroforestry species found in different habitats in Guinean zone. The Departments of Ouémé and Plateau are the areas of high population of breadfruit tree (Azokpota, 2012). The lives of rural people are intimately linked to the three pillars of food, health and income (Akouehou, 2012). The fruit of Artocarpus communis by its nutritional characteristics and its organoleptic qualities, is part of the Non-Timber Forest Products (NTFPs) consumed by the rural population to effectively fight against food insecurity. For this fact, in welding period, the breadfruit tree are the base food of rural people and is also substituted for its roots and tubers as yam, cassava and sweet potato. These functional characteristics has been shown in West Africa (Adepuju et al., 2011). In Bénin, some flow markets of fruit has been known (Akouehou, 2014). Artocarpus communis is one of the most widely used species in Pacific (Zerega et al., 2004); (Ragone D, 2006); (Ragone D, 2011); contribute to reduce the poverty (Labouisse, 2016) and were used in pharmacology (Baba et al.,2016) All these studies proves the ethnobotanical knowledge importance of A. communis synonymous with A. Altilis (The Plant List, 2013a). For this reason, in order to value and best conserve this species, this preliminary study conducted in all areas of distribution of the species in South Benin comes to access the state of the species. The objective of this study is to assess ethnobotanical knowledge and the economic importance of A. communis. More specifically, it was a question of having a precise idea about the organs used, the different uses, the methods of sampling, the places of harvest, the breadfruit tree cropping systems, acreage, yields, geographical distribution, marketing channels for breadfruit tree fruit, quantities trade, selling prices, existing modes or forms of processing, times and places of selling of the breadfruit and its profitability.

\section{Study area}

The study took place in southern Benin in the phytogeographic district of the Valley of Ouémé distributed among Adjohoun, Akpro.missrete and Sèmè.kpodji communes who is located between $6^{\circ} 40^{\prime} 0^{\prime \prime}$ of North Latitude and $2^{\circ} 30^{\prime} 0^{\prime \prime}$ of East Longitude, the phytogeographic district of Plateau into Kétou, Sakété and Ifangni communes who is located between $7^{\circ} 10^{\prime} 0^{\prime \prime}$ of North Latitude and $2^{\circ} 35^{\prime} 0^{\prime \prime}$ of Longitude East, and the coastal Phytogeographic district of calavi, Tori-bossito and ouidah communes, located between $6^{\circ} 40^{\prime} 0^{\prime \prime}$ of North Latitude and $2^{\circ} 15^{\prime} 0^{\prime \prime}$ of Longitude East. 


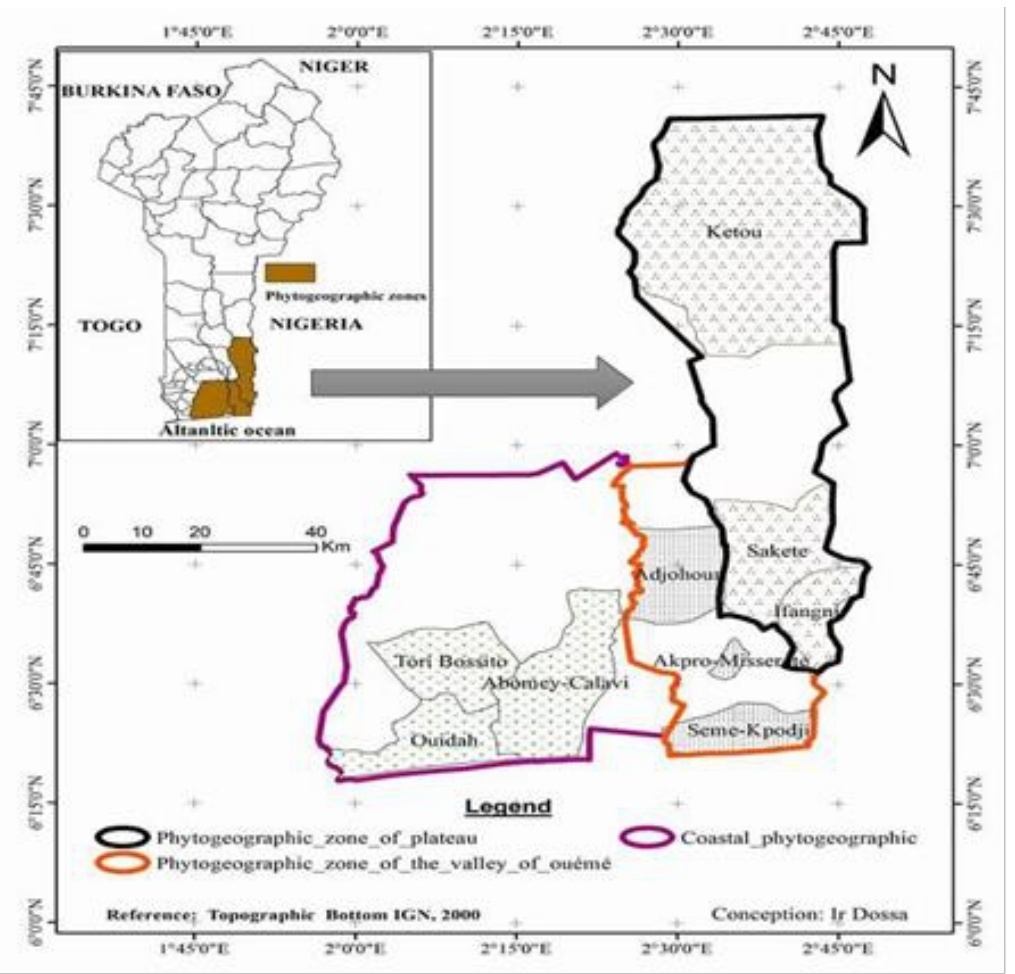

Figure 1: Field of study, Realized by (Dossa, 2015)

\section{Methodology}

\section{Materials}

The plant material consists of Artocarpus communis trees of the Moraceae family. This is a breadfruit tree that was introduced in Benin from the West India (FAO, 2010). Breadfruit is an evergreen tree that can reach $15-20 \mathrm{~m}$ in height. The trunk extends between $60 \mathrm{~cm}$ and $1 \mathrm{~m}$ in diameter. The leaves are highly variable in shape, mainly about 45 centimeters long but can be ranged from 15 to 90 centimeters depending on the variety (Ragone D, 2006). It is grows in very varied climatic environments and can even grow to around $1550 \mathrm{~m}$ of altitude (Ragone D, 2011). The fruits are often round, oval or elongated weighing $0.25-5 \mathrm{~kg}$ from 10 to 30 centimeters in diameter. In Benin, A. communis is distributed from Kétou height to Allada.



Photo1: Leaves and Fruits

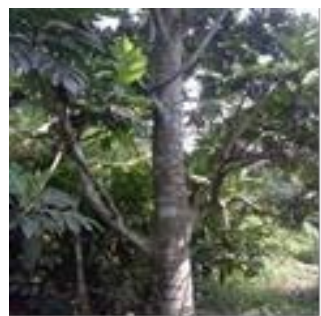

Photo2: Trunk

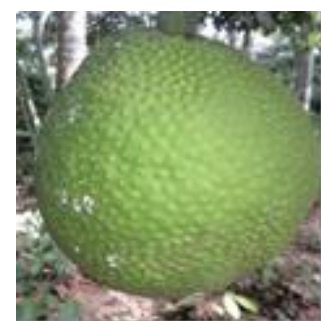

Photo3: Fruits Source: (Dossa 2015) 


\section{Sampling and data collection}

On the basis of demographic data, different sociolinguistic groups were formed according to age (Young, Adult and Old); sex (Men, and Women) and ethnics group (Mahi, Tori, Fon, and Nagot or Yoruba). The data were collected through the surveys based on semi-structured interviews and focus groups founded mainly on the triangulation method of information using in different communes. The choice of informants on the species in each locality was made in eachs randomly ethnic group. The age of informants was limited to 20 years for having a better knowledge of NTFPs. The information collected made it possible to identify the levels of ethnobotanical knowledge and the uses of the breadfruit tree according to the different groups. Three villages (Ouidah, Calavi, Tori-Bossito) were randmly chosen in the Coastal phytogeographic zone; three (Semè-kpodji, Adjohoun, Akpro-Missrété) in the phytogeographic zone of the Ouémé's Valley, and also three (Sakété, Ifangni, Kétou) in phytogeographic zone of plateau. At the level of each of these communes, preliminary surveys were carried out on 100 individuals randomly sampled and the proportion (Fn) of the respondents recognizing at least one use of the species was determined. For all of these preliminary surveys in the study area, it was obtained an average that $91 \%$ of respondents had knowledge of at least one use of the species. Thus the proportion obtained is the $\mathrm{p}$ that we introduced into the (Dagnelie, 1999) formula to find the size of the sample to be investigated.

$$
\mathrm{n}=\frac{\mathrm{U}_{1-\alpha / 2}^{2} \times \mathrm{p}(1-\mathrm{p})}{\mathrm{d}^{2}}
$$

n: sample size considered

p: proportion of informants who use the species in the exploratory phase $(\mathbf{p}=$ 0.91); $\mathbf{U}_{1-\alpha / 2}$ : value of the law normal to the probability value 1- $\alpha / 2=\mathbf{0 . 9 7 5}$; with $\alpha=5 \%$ is $\mathbf{1 . 9 6} ; \mathbf{d}$ : margin of error of the estimate set at a value of $\mathbf{4 \%}$. Referring to the hypothesis of reduced normal law, the size of our sample is 393.28 for which we decided to retain 396 people for the three phytogeographic zone. In Coastal phytogeographic zone, 178 people were investigated, 140 in the phytogeographic zone of the Valley of Ouémé, and 78 in phytogeographic zone of plateau. The collected data are relative (a) to the local name of species, (b) to the degree of knowledge of the species, (c) to the organs taken from the species, (d) to the harvesting method, (e) the places of harvest, (f) the income, (g) the main uses of the species relating to different socio-cultural groups (ethnic groups, age, sex). Yoruba and related, Fons and relatives, and finally Adja and related are the most represented ethnic groups in the study area. 
Table I: Summary of sampling by districts

\begin{tabular}{|l|c|c|c|c|c|c|}
\hline \multirow{2}{*}{$\begin{array}{l}\text { Demographical data } \\
\text { Districts }\end{array}$} & \multicolumn{3}{|c|}{ Inhabitants } & \multicolumn{4}{c|}{ Ethnic group } & $\begin{array}{l}\text { Areas } \\
\left(\mathrm{km}^{2}\right)\end{array}$ \\
\cline { 2 - 7 } & Men & Women & $\begin{array}{l}\text { Fon and } \\
\text { related }\end{array}$ & $\begin{array}{l}\text { Nagot and } \\
\text { related }\end{array}$ & $\begin{array}{l}\text { Adja and } \\
\text { related }\end{array}$ & Total \\
\hline Oueme & 110 & 68 & 140 & 18 & 20 & 1281 \\
\hline Plateau & 60 & 18 & 23 & 54 & 1 & 3264 \\
\hline Coastal & 95 & 35 & 107 & 11 & 22 & 3233 \\
\hline
\end{tabular}

\section{Data analysis}

The respondents were grouped by socio-cultural group (Fon, Nagot, Mahi, Goun and Tori) and by age-sex category (young men and women, adult men and adult women, old men and old women). They were divided by sociolinguistic groups and by gender. For this fact six (10) subgroups have been formed, namely: Mahi Man (HM), Mahi Women (FM), Gouns Men (HG), Gouns Women (FG), Fon Men (HF), Fon Women ( FF); Men Nagot (HN), Women Nagot (FN) and Men Tori (HT), Women Tori (FT). In this study, from each group, six (06) subunits were formed : Young Men (JH) and Young Women (JF) are people aged between 20 - 35, Adult Men (HA) and Adult Women (FA), which age varies between 36 - 50 years old and Old Men $(\mathrm{VH})$ and Old Women (FV), over 51 years old. For ethnobotanical knowledge, Principal Component Analysis (PCA) was performed on IVO data matrices based on age and sex categories on the one hand, IVO and sociolinguistic groups to better describe the relation between the various uses of the organs and the categories of actors (Ethnics, age, sex) and on the other hand to better describe the relations between the IVO of A. communis and the age, sex and sociolinguistic groups. The ANOVA mean comparison test will be used to compare the indices of diversity by socio-cultural groups (ethnics, age, and sex) using the R3.2.4 software. The Factorial Correspondence Analysis is used to establish. To best appreciate the distribution of ethnobotanical knowledge of $A$. communis according to linguistic groups, gender and sex different ethnobotanical indices were calculated to determine the distribution of knowledge such as: the value of total ethnobotanic use (VUT), the diversity index (ID) and the evenness index (IE) and the use value (IVO) of A. communis in communities (Table 1). The non-parametric KruskalWallis test was used to compare the ID according to socio-cultural groups and age-sex categories since the data collected were not normally distributed (Ryan-Joiner Normality Test).

\section{Respondent diversity index (ID)}

Diversity value measures diversity categories of use of the species and present how this knowledge is distributed among the respondents (Shannon, 1948 and Byg et al., 2011). It is defined by the formula. 


$$
I D=-\sum \frac{n i}{N} \log _{2} \frac{n i}{N}
$$

ni is the number of uses cited by the respondent and $\mathbf{N}$ is the total number of identified uses. If all the respondents have the same knowledge on $A$. communis, the value of the index is maximum and equals $I D \max =\log 2 \mathrm{~N}$ where $\mathbf{N}$ is the total number of respondents. Diversity is low when ID $<3$; average if ID is between 3 and 4; then high when ID $\geq 4$. A low index value would mean that a small group of respondents holds most of the knowledge about A.communis.

Equitability index of the respondent (Pielou, 1969)

It is given by the formula and measures the degree of homogeneity of knowledge of the respondents. It is between 0 and 1 . If IE $<0.5$ the diversity of knowledge respondents is not homogeneous but if $\mathrm{IE} \geq 0.5$ this diversity is homogeneous. It means a distribution equitable knowledge within populations investigated for the use of the species.

$$
I E=\frac{I D}{I D \max }
$$

\section{Consensual value on types of usage}

It measures the degree of concordance between investigated with regard to the uses made of the species (Monteiro et al, 2006). She is expressed by:

$$
C T U=\frac{2 n i}{n}-1
$$

Where $n i$ is the number of people using $A$. communis in a given usage category and $n$ the number total of interviewees. It is between [-1 and 1].

If $n i=0 ; \mathrm{CTU}=-1$ and if $n i=n ; \mathrm{CTU}=1$. This translates the degree of consensus of respondents on a particular use.

From the economic point of view, the average gross income from the production of fruits has been determined by subtracting the variable costs from the turnover. In other words, the unit price of the fruit is multiplied by the average number of fruit per plant and the number of plants per hectare.

Table 2 : Ethnobotanical usage value

\begin{tabular}{|l|l|l|l|l|}
\hline $\begin{array}{l}\text { Calculate } \\
\text { d values }\end{array}$ & Definition & Determination & Reference \\
\hline VUT $=$ & $\begin{array}{l}\text { VU (i) = usage value of } \\
\text { the individual (i) } \\
\text { VUT TUT is calculated as the } \\
\text { ethnobotanical usage } \\
\text { value of all individuals; }\end{array}$ & $\begin{array}{l}\text { VUT is allow to determine significantly } \\
\text { sum of the usage values of } \\
\text { a species within the } \\
\text { different usage categories }\end{array}$ & $\begin{array}{l}\text { It we species with high usage value and } \\
\text { will be considered in the } \\
\text { participatory management device }\end{array}$ & $\begin{array}{l}\text { (Lykke et al., } \\
\text { Belem et al., } \\
\text { 2008) }\end{array}$ \\
\hline
\end{tabular}




\section{Results/Discussion}

\section{Résults}

\section{Ethnobotanical knowledge of $\boldsymbol{A}$. Communis}

The local populations of Benin surveyed know Artocarpus communis for decades.

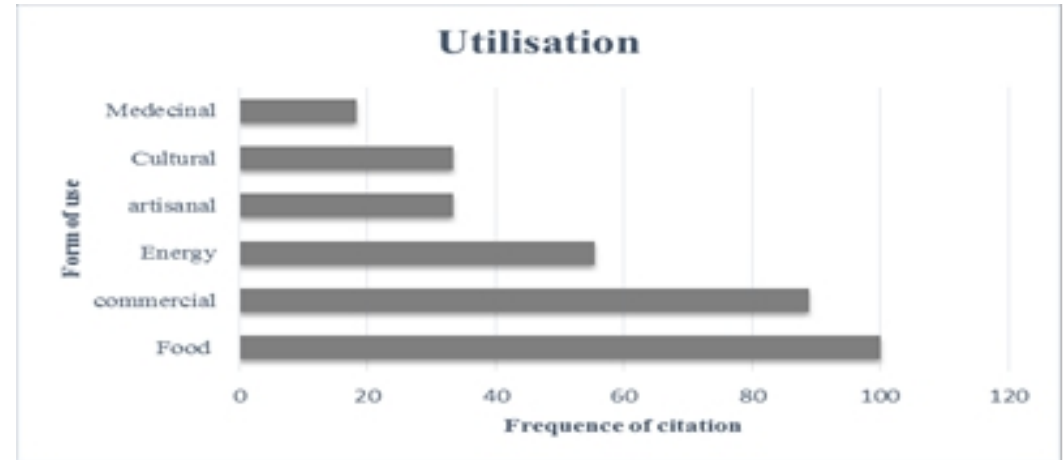

Figure 2 : Different forms of A. communis uses

The Figure 2 shows the different forms of $A$. communis use based on the citation frequencies. The analysis of this shows that $\mathrm{A}$. communis has six (06) different functions at the level of the local populations. The main use is food (100\% of respondents), medicinal (18.33), energy $(55.55 \%$ of respondents), artisanal (33.33\% of respondents), cultural $(33.33 \%$ of respondents) and commercial (88.88\% of respondents).

\section{Consensual value on the types of usages of $A$. Communis}

Table 3 : Consensual value on the types of $A$. Communis uses

\begin{tabular}{|l|c|}
\hline Food & Types of use \\
\hline Trade & 0.35 \\
\hline Wood-energy & 0.22 \\
\hline Craft & 0.14 \\
\hline Culturals & 0.08 \\
\hline Medicinal & 0.08 \\
\hline
\end{tabular}

The fruit is the most important organ consumed by the local population $(\mathrm{CTU}=0.35)$. The commercial use of the species is known by the majority of the socio-cultural groups in southern Benin as a significant source of income and is ranked second $(\mathrm{CTU}=0.22)$. Dry branches are used as firewood (CTU $=0.14)$. The species is poorly used in medicinal $(\mathrm{CTU}=0.04)$, artisanal which means that it is used as lumber in the making of canoes, doors, windows (CTU $=0.08$ ) and cultural used in the manufacture of Tam-Tam, guitars, sculpture, homemade balls, coffins, $(\mathrm{CTU}=0.08)$. 


\section{The use value of the organs of $A$. Communis}

The fruit of A. communis is more used by local people in the diet (VUT $=11.87)$. Roots are ranked second and are used a few times for breeding and recipes $(\mathrm{VUT}=6.89)$; the trunk is used in crafts and culture (VUT $=1.85)$; the leaves $(\mathrm{VUT}=0.525)$; the bark $(\mathrm{VUT}=0.375)$ and the flowers $(\mathrm{VUT}=0.225)$ are used for medicinal purpose not really important in the area (Table 4).

Table 4 : The usage values of organs

\begin{tabular}{l|l|l|l|l|l|l}
\hline Organ & Fruit & Roots & Flower & Trunk & Leaves & Bark \\
\hline VUT & 11.87 & 6.89 & 0,225 & 1.85 & 0.525 & 0.375 \\
\hline
\end{tabular}

A total of 23 diseases and symptoms were identified and treated by the species. All the organs of the plant are used but in different degrees namely the roots $(10,75 \%)$, the bark $(22,59 \%)$, the leaves $(15,05 \%)$, the fruits $(43$, $01 \%)$ and the flowers $(8,60 \%)$.

Table 5. Different medicinal uses of Artocarpus communis

\begin{tabular}{|l|l|l|}
\hline Roots & $\begin{array}{l}\text { Typhoid fever, Palpitation of the heart, } \\
\text { Anemia } \\
\text { Malaria }\end{array}$ & $\begin{array}{l}\text { Boil the roots and lemon } \\
\text { with water Make an infusion } \\
\text { of ripe leaves fallen to the } \\
\text { ground to treat anemia, } \\
\text { malaria and regulate blood } \\
\text { pressure and Malaria }\end{array}$ \\
\hline $\begin{array}{l}\text { Barks, } \\
\text { Leaves }\end{array}$ & Scabie, Measles, Reviving, Dysentery & $\begin{array}{l}\text { Make an infusion of the } \\
\text { bark and take a bath }\end{array}$ \\
\hline Flowers & External and internal hemorrhoid & $\begin{array}{l}\text { Dry the flowers, grind them } \\
\text { and mix with shea butter } \\
\text { then apply them on the anal } \\
\text { part }\end{array}$ \\
\hline Fruit & Sexual weakness & $\begin{array}{l}\text { Wash the fruits thoroughly } \\
\text { and boil them thoroughly } \\
\text { with the skin to collect the } \\
\text { juice that settles in the pot } \\
\text { after cooking }\end{array}$ \\
\hline
\end{tabular}

\section{Mode of collection, Organ harvesting locations and frequency of harvest}

We are distinguish three mode of collecting organs of breadfruit: picking, collecting and The producers reap the fruits, flowers and cutting. In all departments (Atlantic, Ouémé and Plateau) considered and no matter the ethnicity and age, $50.51 \%$ of the total of the people surveyed remove organs (Fruit, Roots, Leaves, Bark, Flower, Trunk) around homes; $14.65 \%$ of the respondents in the fields; $11.62 \%$ in low background and $23.23 \%$ in fallow lands. This is because the majority of the respondents have at least one breadfruit tree in their homes. 


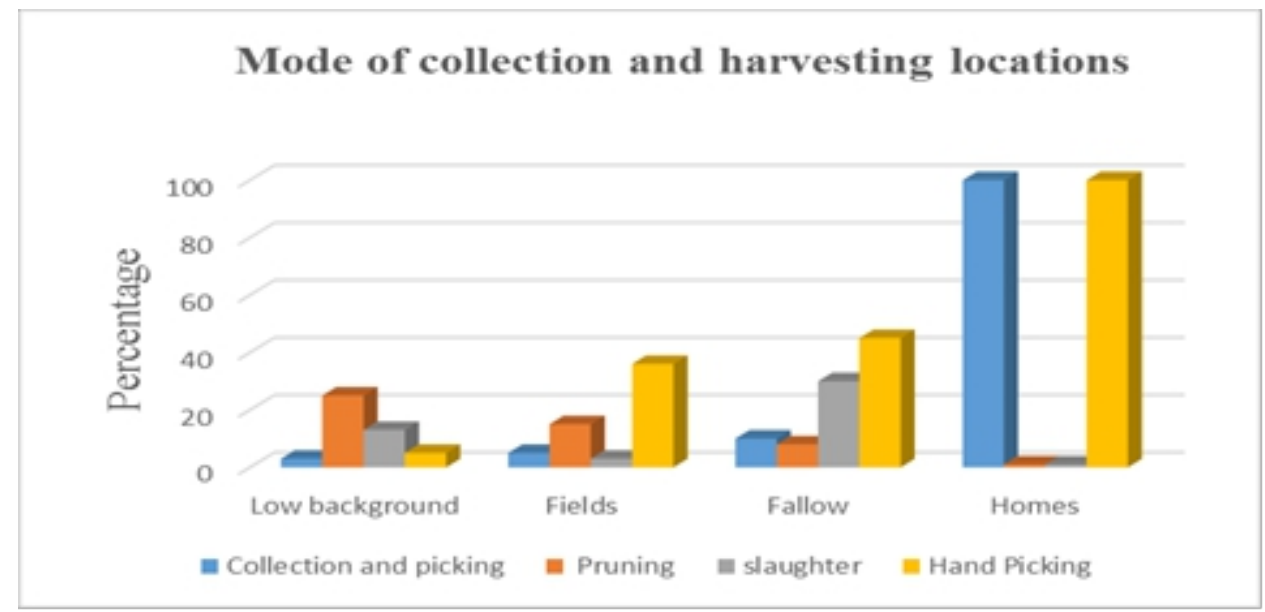

Figure 3 : Sampling locations of the various organs

\section{Relationship between uses and different ethnic groups}

The analysis of relationship between the use of organs A.communis and the different ethnic groups reveal that the two axes (Dim 1 and Dim 2, Figure 5) account for $84.97 \%$ of the total variance in the information set. Three different groups link ethnic groups and different uses of the species Artocarpus communis (blélèfutu) were discriminated. Group 1 (G1) connects ethnics (Mahi and Nagot) to exclusively food uses, wood and medicinal energy. This group is opposed to group 2 which links ethnic Fon to usages of wood energy, food and culture. Axis 2 opposes group 2 (G2) to group 3 (G3) connecting the Tori and goun ethnics to usages of food, cultural, medicinal and craft. This means that all ethnic groups use in common the species Artocarpus communis for human consumption and wood energy. Unlike Nagot and Mahi, the Fon, Tori and Goun makes exclusively a cultural use of the species but only the Tori, Goun and Fon makes an artisanal use. The diversity index varies significantly based on the ethnic (Kruskal $=84$, $34, p<0.05$, Figure 6), suggesting that the diversity of usages depending on the sex, age and ethnicity is dependent. Tori and Fon have the highest diversity of usage $(0.7<\mathrm{ID}<0.8)$. Afterwards, Goun and Mahi $(0.5<\mathrm{ID}<0.6)$. Finally Mahi and Nagot have the lowest of usage $(0.3<$ ID $<0.5)$. 


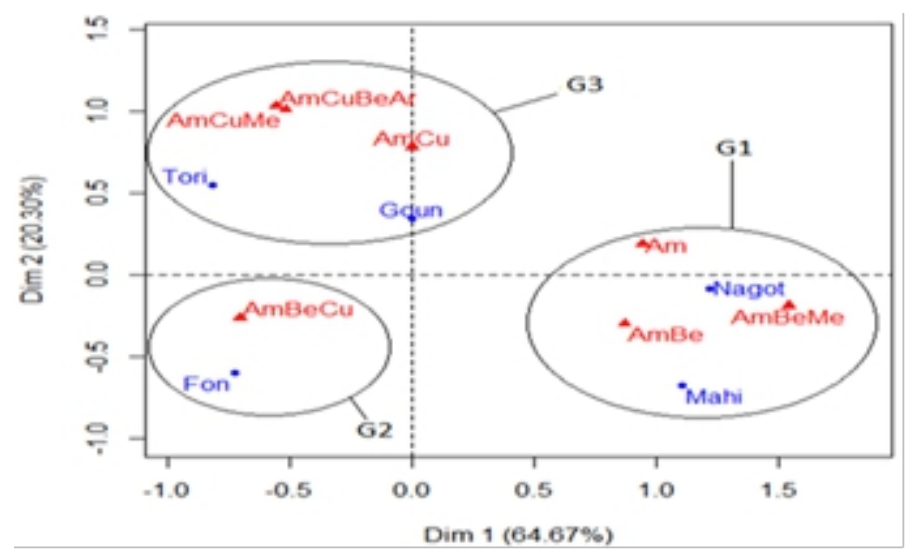

Figure 4: Relationship between socio-cultural groups and usages

The index of total diversity of respondents (ID) shows that all age groups (Young Men and Women ID $=0.44$ and ID $=0.19$; Adult Men and Women ID $=0.54=0.22$ ID and finally Old Men and Women ID $=0.49$ and $\mathrm{ID}=0.26)$ use the species. Young people have relatively little knowledge compared to adults and old people. Knowledge about the types of usages are unequally distributed among respondents based on gender. In contrary, the index of total fairness of respondents (IE) indicates that for classes of age (Young Men and Women = IE 0.03 and IE = 0.03; and Old Men and Women IE $=0.07$ and $\mathrm{IE}=0.07)$ knowledge is distributed between the two sexes uniformly among Adults Men and Women IE $=0.06$ and $=0.03$ IE the allocation is less homogeneous. These results demonstrate that the Old particularly men make more use of the species than other groups. Among the discriminating factors when it comes to knowledge and usage of the species, the gender and the species come first.

Table 6: Index of diversity and distribution of knowledge within surveyed people based on gender and age

\begin{tabular}{l|l|l|l|l|l|l}
\hline & JH & HA & VH & JF & FA & VF \\
\hline ID & 0.44 & 0.54 & 0.49 & 0.19 & 0.22 & 0.26 \\
\hline \hline IE & 0.03 & 0.06 & 0.07 & 0.02 & 0.03 & 0.07 \\
\hline
\end{tabular}

$\mathrm{JH}=$ Young Men; At $\mathrm{H}=$ Men Adults; $\mathrm{VH}=$ Old Men; JF = Girls; $\mathrm{AW}=$ Women Adults; VF $=$ Old Women. 

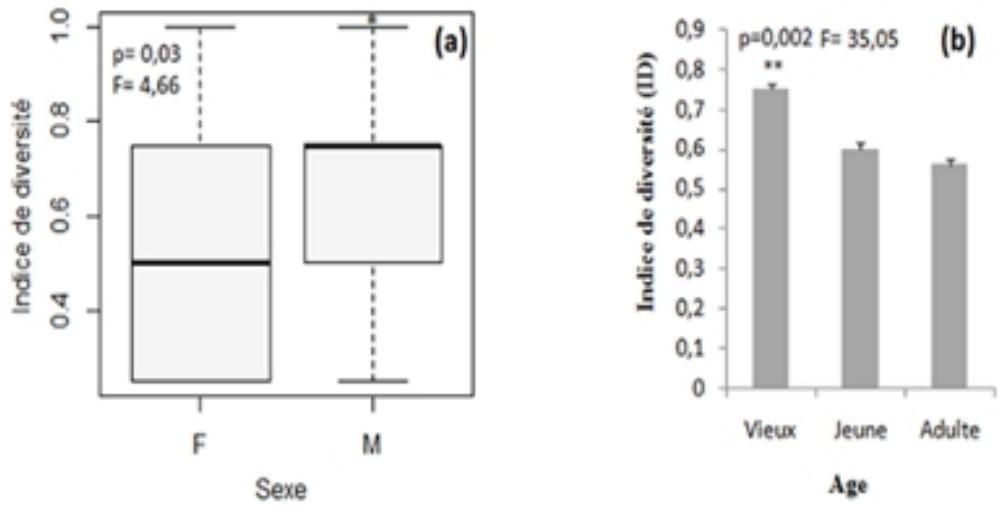

Figure 5 : a- Diversity of uses according to sex b- Diversity of uses of A. communis according to age

The results reveal that the diversity index significantly varies according to the sex $(F=6, p=0.03$, Figure 6$)$ and age $(F=35.05, p=0.002$, Figure 8 ) and suggests that the diversity of usages according to gender and age is dependent. The diversity was significantly higher with men than women, suggesting that men make various usages of the species. Diversity is also higher among older than among adults and young people (Figure 7). Some social groups including older people hold relatively more knowledge on the species usages than others.

\section{Economic importance of breadfruit tree (A. communis)}

The fruit of the breadfruit tree (A. communis) is traded for its food usage. A. communis bears fruit twice a year. There are baskets containing 5, 10 and 40 fruits. Parameters such as the size of the fruit are used in trading. Thus, the fruits of small sizes are sold at a price of 4,000 FCFA while the average ones are sold 6000 FCFA and the biggest fruits 10000 FCFA the basket of 40 fruits. The Gouns trade the roots for its use in the reproduction of the species. The price of a unit of fruit varies between 100FCFA to 150FCFA. As for its use as firewood no sociolinguistic groups trades it. For its cultural and craft use the price of a timber is 10000FCFA. To assess the socioeconomic importance of sociocultural groups at one hand, forty-five (45) orchards have been part of the survey and were taken randomly. On the other hand, an orchard contains 70 plants, the mean yield of fruit is 17 tonnes/ha. Variable costs are production costs related to agricultural inputs (fertilizers, pesticides, seeds, amendment, hired labor, etc...) and are based on the total quantity produced. This production is based on fields already cultivated.

To assess cash flow of the fruit trading, the following formula was established: 


$$
\mathbf{R}=\mathbf{P f} * \mathbf{N f} * \mathbf{N p}-\mathbf{C}
$$

$\mathrm{R}=$ Income (Cash Flow), $\mathrm{Pf}=$ Unit Price $/$ fruit, $\mathrm{Nf}=$ Average fruit, $\mathrm{Np}=$ Number of plants bearing fruit per hectare, $\mathrm{C}=$ variable costs

Table 7 : Income (Cash Flow) from Artocarpus communis fruit trading by department

\begin{tabular}{|l|c|c|c|}
\hline Parameters & Ouémé & Plateau & Atlantique \\
\hline Number orchards & 9 & 16 & 30 \\
\hline $\begin{array}{l}\text { Number of non- } \\
\text { load bearing }\end{array}$ & 150 & 1950 & 630 \\
\hline $\begin{array}{l}\text { Tree Number } \\
\text { carriers }\end{array}$ & 960 & 585000 & 53550 \\
\hline $\begin{array}{l}\text { Average quantity of } \\
\text { fruit harvested }\end{array}$ & 153550 & 0,18 & 0,18 \\
\hline $\begin{array}{l}\text { Unit Price means } \\
\text { (USD) }\end{array}$ & 0,18 & 104651,16 & 19159,21 \\
\hline Selling Price (USD) & 27468,69 & 13652,95 & 2726,29 \\
\hline $\begin{array}{l}\text { Variable costs } \\
\text { (USD) }\end{array}$ & 7270,12 & 90998,21 & 16432,91 \\
\hline $\begin{array}{l}\text { Average value of } \\
\text { sales (USD) }\end{array}$ & 20198,56 & 127629,69 & \\
\hline Total & & & \\
\hline
\end{tabular}

Based on this calculation, the average income per hectare is therefore estimatedat 2836USD/person/year.

Among different sociolinguistic groups, Fon and related own several markets for selling (Porto Novo, Cotonou, Ketu, Sèmè-Kpodji, Calavi, etc.) compared to the Yoruba and related and the Adja and related, this classifies them among the ethnic groups that have the highest income mean that is 55915 USD /year. In contrary, from the perspective of the gender aspect, men have a considerable income of 91353 USD /year compared to women estimated at 36276 USD /year. From the perspective of age, adults have an income which amounts for 72728 USD /year compared to young 41595 USD /year and the old people 13307 USD/year.

\section{Discussion}

\section{Social importance}

Breadfruit tree (Artocarpus communis) is a multifunction species. Food, medicinal, craft, trade, cultural, energy uses by socio-cultural groups show that the species has a great social importance for local people. These different forms of valuations of the species were also reported by other authors like (Ragone D, 2006), (Ragone D, 2011), (Akouehou et al., 2014) on Artocarpus altilis and also on other species such as Prosopis africana by (Houètchégnon et al., 2015). The similarity in the uses can be 
explained by the existence of a long history of use of this species that has been incorporated into the food habits of the populations.

\section{Consensual value on the usages and the different parts of $A$. Communis}

The agreement between the respondents on the usages of the species is more important on food uses $(\mathrm{CTU}=0.35)$ but very low on the medicinal uses $(\mathrm{CTU}=0.04)$. These results are similar to those of (Akouehou et al., 2014) on A. altilis in phytogeographical district Pobè that observed for food uses, respectively $(\mathrm{CTU}=0.317)$ and medicinal $(\mathrm{CTU}=0.092)$.

The slight variations in the consensus values may be due to the abundance of information gathered from the number of towns in the context of our study. The decline of the degree of agreement on the medicinal uses was due to the low knowledge of on the use organs of the breadfruit tree in pharmacopoeia. The fruit of $A$. communis is today the organ is the most used by local people in the diet (VUT $=11.87)$. These results corroborate those of (Akouehou et al., 2014) on A. altilis which states that the species is used in the food sector. These findings may be due to the fact that the ethnobotanical use value is correlated to the number of uses and therefore to the knowledge of a variety of dishes from its fruit (Fried, boiled, ragout, crushed) by the local population.

\section{Sampling locations of the bodies and organs of the collection method}

The majority of people surveyed $(50.51 \%)$ harvest organs of the species mainly in homes. These results are contrary to those of (Akouehou et al., 2014). This discrepancy may be due to the morphological characteristics of the species, proximity of the case vis-à-vis the people who use it but also the way of harvesting organs that differs from one species to another. The bodies of $A$. communis in particular are collected by picking. These findings are explained by the fact that people use the cuttings to produce a whole plant near homes. They refuse to travel long distance to get organs for food consumption.

\section{Diversity of usages of the species $A$. communis following socio-cultural groups}

The study revealed that local people know the species with an unequal distribution both when it comes to gender with diverse values and total fairness (Men ID = 0.75 and $\mathrm{IE}=0.08$ ) and women (ID and $\mathrm{IE}=0.48=0.06$ ); when it comes to age (Young ID $=0.56$ and IE $=0.07$; Adult ID $=0.606 \mathrm{IE}$ $=0.08$ Old $\mathrm{ID}=0.75$ and $\mathrm{IE}=0.1)$ suggesting that men make various usages of the species. Men tend to have more medicinal uses and craft knowledge than women. This is the same conclusion that (Akouehou et al., 2014) on the social and cultural importance of Artocarpus altilis in southern Benin and 
(Houètchégnon et al., 2015) on Prosopis africana in Benin. This variation uses can be explained by cultural differences and the need of local people. Similarly, information on the use of the species Artocarpus communis are unequally distributed in the different linguistic groups. Also, the use of organs varies slightly and depending on the socio-cultural groups. This can be explained by the fact that each ethnic group has its particularities in terms of food and that the Tori and the Gouns use it the most (production, marketing, traditional medicine, crafts, etc ...). These results corroborate those of (Akouehou et al., 2014)in his study of the socio-cultural importance of Artocarpus altilis in southern Benin which stipulate that the knowledge on the uses are unequally distributed in the different ethnic groups considered and those of (Houètchégnon et al., 2015) endogenous knowledge is cultural and therefore vary from one ethnic group to another. In fact, when it comes to age ( $p=0.002 \mathrm{~F}=35.05 \mathrm{ID}=0.7)$, the old have a deeper knowledge of the uses of the species. These results are similar to those obtained by (Djègo et al., 2011) on Antiaris toxicaria and (Dadjo, 2011) on Vitex doniana. This specifically implies that the male has a proven track record of the species uses. The study shows a low transmission of information from a generation to another. These findings are similar to those of (Akouehou et al., 2014) which notifies that although men have more knowledge about the species than women, the values of these parameters for the category of ages do not indicate a remarkable difference between youth and adults in these groups. This shows that, contrary to the findings reported by (Hanazaki, 2000); (Begossi et al, 2002) and (Amorozo, 2004), the valuation level and therefore knowledge of $A$. altilis increases very little with age. This may reflect a transfer of knowledge from generation to generation in order to ensure homogeneity of knowledge in the field.

\section{Economic importance of $A$. Communis}

The different organs of $A$. communis used for various purposes are traded. However, the important income come from the sale of fruit. Based on annual production of orchards of southern Benin, the substantial income means from annual selling of fruit are breadfruit tree are 127630 USD/year. These incomes are inferior to those obtained by (Ragone D, 2006) in the State of Virgin Island in the United States, the value of the sale is estimated at 450217 USD. This difference is explained by the high number of orchards (5813) of the study used for the determination of the average income from the sale of fruit. In contrary, the personal average income per farmer is around 2836 USD. This result is higher than those obtained by (Laura B. Roberts-Nkrumah et al. 2013) in Trinité-et-Tobago estimated at 1135 USD. Falling incomes of farmers of Trinité-Tobago can be explained by the prohibition of the cultivation of the breadfruit tree in the area. The incomes 
observed in our study are much higher than those of (FAO, 2002) at Savé and Glazoué in Benin on hypocotyls of palmyra varying between 62 USD and 104 USD. This net difference is explained by the fact that the calculated income took into account the trade of other sub-products including hypocotyls.

\section{Conclusion}

The study of the socio-economic and ethno-botanic importance of the breadfruit tree (A. communis) in the departments of Atlantic, Ouémé and Plateau identified six (06) forms of use (food, medicinal, energy, craft, trade and cultural) of the species. The fruit with its diversity of cooking (fried, boiled, stewed and crushed) is the organ most exploited for the fact that it meets the needs of local populations and fights food insecurity. The various organs are collected mainly in homes, in fields, in dregs through the picking by hand, with a knife or collection of fruits on the ground. Ethnobotanical knowledge of the species are unequally distributed according to gender, age and socio-linguistic groups. The local people cultivate the species close to homes and in fields for consumption and trade of the organs used for diverse purposes. The income contribution to the rural population in terms of sales of the fruit is estimated at 2836 USD/year.

\section{References:}

1. Adepeju A.B., Gbadamosi S.O., Adeniran A.H., Omobuwajo T.O. (2011). Functional and pasting characteristics of breadfruit (Artocarpus altilis) flours. African Journal of Food Science Vol. 5(9), pp. 529-535. 82p.

2. Akouehou G. S. (2012). Evaluation et analyse socio-économique des marchés des produits forestiers non ligneux, cas du Néré, du Karité, du Rônier, du Baobab, du Pommier sauvage et de l'Arbre à Pain : les chaines de commercialisation, les différents maillons, les caractéristiques, les différents acteurs directs et indirects, les interrelations et les différents flux dans les zones d'intervention du projet. Rapport FAO. Cotonou. 118p.

3. Akouehou S. Gaston, cédric A. Goussanou, rodrigue I. Dohou, florentin E. Dissou, paulin Azokpota. (2014). Importance socioculturelle de Artocarpus altilis (Parkinson) Fosberg (Moraceae) au Sud-Bénin. Journal of Applied Biosciences 75:6173- 6182 ISSN 1997-5902.

4. Amorozo. (2004). Uso de plantas medicinais por caboclos do baixo Ama-zonas, Barcarena, PA, Brasil. Boletim do museu Paraense Emilio Goeldi, Serie Botanica.

5. Azokpota P. (2012). Technologie de transformation de six espèces forestières prioritaires non ligneuses: Néré, Karité, Rônier, Baobab, 
Pommier sauvage et Arbre à Pain. Deuxième rapport de consultation. Rapport FAO. Projet d'Appui à la promotion et à la valorisation des Produits Forestiers Non Ligneux» (PA-PFNL) au Bénin. PCT/BEN/3303, Bénin.

6. Begossi. (2002). Plant uses at Bizios Ishand. Journal of Ethobiology 13 (2) 233-256.

7. Belem B., J.I. Boussim, R. Bellefontaine et S. Guinko. (2008). Stimulation du drageonnage du bombax costatum Pelegr. Et vuillet par blessures de racine au Burkina Faso. Bois et Forêt des Tropiques. 295. (1). 71-79.

8. Byg A. and Baslev H. (2011). Diversity and use of palms in zahamena, eastern Madagascar. Biodiversity and conservation. 10, 951-970.

9. Dagnelie, P. (1999). Statistiques théoriques et appliquées. Brussels : De Boeck. 517 p.

10. Dadjo, C. (2011). Caractérisation ethnobotanique, morphologique et spatiale de vitex doniana sweet (verbenaceae) au Sud-Bénin. Thèse pour l'obtention du diplôme d'ingénieur Agronome, Université d'Abomey-Calavi. 56p

11. Djègo J., S. Djègo-Djossou, Y. Cakpo, P. Agnani \& B. Sinsin. (2011). Evaluation du potentiel ethnobotanique des populations Rurales au sud et au centre du Bénin. Laboratoire d'Ecologie Appliquée, Faculté des Sciences Agronomiques, Université d'Abomey-Calavi, $18 \mathrm{p}$. International Journal of Biological and chemical sciences.

12. FAO.(2002). Food and nutrition service. http://en.wikipedia/wiki/preservation.

13. FAO. (2010). State of the world's forests''. Rome, Italy: FAO. Food and Agricultural Organization

14. Hanazaki N., Tamashiro J. Y., Leitao-Filho H.F., Begossi A. (2000). Diversity of plant uses in two caicara communities from the Atlantic Forest Coast.

15. Houètchégnon, T., Gbèmavo, D. S. J. C. Ouinsavi, C. and Sokpon, N. (2015b). Ethnobotanical knowledge and traditional management of mesquite (Prosopis africana Guill, Perrot. et Rich.) populations in Benin', West Africa. In press The Journal of Ethnobiology and Traditional Medicine. Photon 125, 1124-1135. Chemical Sciences, Vol5,No4.

https://www.ajol.info/index.php/ijbcs/article/viewFile/75919/66414

16. INSAE. (2016). Institut National de la Statistique et de l'analyse Economique: Résultats définitifs du RGPH4.

17. Laura B. Roberts-Nkrumah et al. (2013). Breadfruit (Artocarpus altilis, Moraceae) and chataigne (A. camansi) for food security and Income Generation. 
18. Labouisse Jean-Pierre. (2016). Ethnobotany of breadfruit in Vanuatu: Review and prospects.. Ethnobiology Letters, 7 (1) : 14-23. http://dx.doi.org/10.14237/ebl.7.1.

19. Lykke A.M., Kristensen M.K. et Ganaba S. (2004). Valuation of the local dynamics of 56 woody species in the Sahel. Biodiversity and conservation.13p. 1961-1990.

20. Monteiro, P.M.S., van der Plas, A., Mohrholz, V., Mabille, E., Pascall, A. and Joubert, W. (2006). Variability of natural hypoxia and methane in a coastal upwelling system: Oceanic physics or shelf biology. Geophysical Research Letters 33: doi: 10.1029/2006GL026234. issn: 0094-8276.

21. Moupela C. (2013). Ecologie, dynamique des populations et intérêts économiques du noisetier d'afrique (coula edulis baill.) au gabon. PhD. Université de liège - gembloux agro-bio tech, Académie universitaire wallonie-europe. Belgique $144 p$.

22. Ragone D, and Cavaletto CG. (2006). Sensory evaluation of fruit quality and nutritional composition of 20 breadfruit (Artocarpus, Moraceae) cultivars. Economic Botany 60(4):335-346.

23. Ragone D. (2011). Farm and Forestry Production and Marketing Profile for breadfruit (Artocarpus altilis). Elevitch, C.R. (ed.). Specialty Crops for Pacific Island Agroforestry. Permanent Agriculture Resource (PAR) Holualoa. Hawai. Specialty Crops for Pacific Island Agroforestry. (http://agroforestry.net/scps).

24. Pielou, E.C. (1969). An introduction to mathematical ecology. Wiley, New York. Wiley Interscience. John Wiley \& Sons, VIII + 286 S., 32 Abb., Preis 140 S. PP 219-220.

25. Shannon, C. E. (1948). A mathematical theory of communications. Bell Syst. Techn. J., 27:623-656.

26. Shigeyuki Baba, Hung Tuck Chan, Mio Kezuka, Tomomi Inoue, Eric Wei Chiang Chan. (2016). Artocarpus altilis and Pandanus tectorius: Two important fruits of Oceania with medicinal values, Emirates Journal of Food and Agriculture. 2016. 28(8): 531-539doi: 10.9755/ejfa.2016-02-207http://www.ejfa.me/

27. The Plant List. 2013b. Pandanus. Database. Available from: http://www.theplantlist.org. [Last accessed on 2016 Jan 02]

28. Emirates Journal of Food and Agriculture. 2016. 28(8): 531-539 doi: 10.9755/ejfa.2016-02-207 http://www.ejfa.m

29. Zerega, N. J. C., D. Ragone, and T. J. Motley. 2004. Complex Origins of Breadfruit (Artocarpus altilis, Moraceae): Implications for Human Migrations in Oceania. American Journal of Botany 91:760-766. DOI:10.3732/ajb.91.5.760. 